\title{
HUBUNGAN PENGETAHUAN PEGAWAI DENGAN PEMILAHAN LIMBAH PADAT DI RUMAH SAKIT UMUM SEMBIRING TAHUN 2019
}

\author{
Yunita Syahputri Damanik, Khoirul Bahri \\ INSTITUT KESEHATAN DELI HUSADA DELI TUA \\ JL.BESAR NO.77DELI TUA, DELI SERDANG SUMATERA UTARA \\ e-mail : Yunitadamanik88@gmail.com
}

\begin{abstract}
:
Medical activities in the polyclinic room, ward, operating theatre and laboratory. The danger that comes from hospital medical waste which causes disease or injury. Medical waste exposure especially sharp object which causes virus infection like Human Immunodeficiency Virus (HIV)/Acquired Immuno Defeciency Syndrome(AIDS) and hepatitis B and C, who are at higher risk of infection because contamined sharp objects are nurses. This research done at the Sembiring Hospital Delitua Deli Serdang Regency. The objectives of this research is to know the relationship of the employees with the sorting of the medical solid waste. The design of this study was survey analytics design with a cross sectional study. The Univariate and bivariate of this research used Chi Square Test. The population of this research is nurses and the total sample is 65 people with the purposive sampling tehnic. The deficient of respondents knowlegde with the sorting of the medical solid waste as much as 35 people $(53,8 \%)$. The sufficient of respondents knowlegde with the sorting of the medical solid waste as much as 16 people $(24,6 \%)$ and the good knowlegde as much as 14 people $(21,5 \%)$. The resulted of the bivariate analitycs with the knowlegde obtained $\mathrm{p}$ value $0.004<\mathrm{a} \mathrm{0.05}$, there is a relationship of employees knowlegde with the sorting of the medical solid waste, it is expect from the hospital to provide periodic checks in the medical waste producing ward to realize the comfort and cleanliness of the hospital environment.
\end{abstract}

Keywords: Knowlegde, Sorting of the medical solid waste, Nurses.

\section{PENDAHULUAN}

Bahaya limbah medis rumah sakit dapat mengakibatkan panyakit atau cidera, pajanan limbah medis khususnya benda-benda tajam dapat mengakibatkan infeksi virus seperti HIV/AIDS serta hepatitis B dan C, perawatdan tegana kesehatan lainnya merupakan kelompok utama yang beresiko paling besar untuk terkena infeksi akibat benda tajam yang terkontaminasi (Pruss, Giroul, dan Rushbrook, 2005).
Angka cedera tahunan akibat limbah medis benda tajam untuk tenaga layanan kesehatan dan tenagakebersihan rumah sakit diajukan oleh US Agency for Toxic Subtances and Diseases Register (ASTDR), jumlah kasus tertinggi infeksi virus hepatitis $B$ di Amerika Serikat adalah dialami oleh perawat yaitu sebanyak 56-96 kasus dan selanjutnya oleh tenaga kebersihan sebanyak 23-91 kasus (Pruss, Giroul, dan Rushbrook, 2005).

Pada tahun 2013, Badan Penelitian dan Pengembangan Kementerian 
Kesehatan RI tahun 2013 menunjukkan data sebanyak 7.000 tenaga kesehatan di Indonesia terinfeksi virus Hepatitis B, dimana 5.000 diantaranya tertular melalui limbah jarum suntik. Hal ini menunjukkan jika tenaga kesehatan termasuk perawat menjadi profesi yang paling rawan terkena cedera sehingga tertular virus Hepatitis B.

Berdasarkan data Depkes RI Juli 2010 ditemukan 8786 kasus HIV akibat tertusuk jarum suntik dan resiko tertularnya HIV dari jarum suntik yang terkontaminasi sebesar 0,04\%. Sedangkan resiko penularan pada hepatitis B sebesar 27-37\%. CDC (Center For Desease Control) melaporkan ada 52 kasus petugas kesehatan terjangkit HIV (Human Immunodeficiency Virus) akibat kecelakaan di luar tempat kerja, sedangkan 144 orang petugas lain diduga terinfeksi di tempat kerja (Depkes RI, 2010). Berdasarkan beberapa penelitian di Indonesia, selain data tersebut diataas terdapat lebih dari 20\% tenaga kesehatan Indonesia pernah tertusuk paling tidak satu kali dalam setahun. Kasus cedera yang dialami oleh para tenaga kesehatan banyak terjadi karena proses memasang tutup jarum suntik sebelum dibuang pada kontainer, melakukan hal yang tidak perlu seperti membuka kontainer tersebut, atau kontainer yang digunakan tidak anti robek. Profil Kesehatan Indonesia tahun 2014 menunjukkan pencapaian Indonesia dalam pembinaan pengelolaan limbah medis rumah sakit sebesar $74,76 \%$ dan belum memenuhi target Kementerian Kesehatan sebesar $75 \%$.

Rumah sakit adalah sarana pelayanan kesehatan yang berlangsung setiap saat selama dua puluh empat jam dan melibatkan berbagai aktivitas orang banyak sehingga potensial menghasilkan berbagai macam jenis limbah baik berupa benda cair, padat dan gas (UU No.44, 2009). Hal tersebut mempunyai konsekuensi perlunya pengelolaan limbah rumah sakit dengan baik sebagai bagian dari kegiatan penyehatan lingkungan yang bertujuan untuk melindungi masyarakat dari bahaya pencemaran lingkungan yang berasal dari limbah rumah sakit Adisasmito, 2007.

\section{METODE PENELITIAN}

Jenis penelitian Kuantitatif dengan metode yang digunakan adalah Survey Analitik dengan pendekatan Cross Sectional yaitu rancangan penelitian yang dalam pengukuran variabel independen dan variabel dependen diukur pada periode yang sama. Penelitian ini dilakukan di Rumah Sakit Umum Sembiring Delitua yang merupakan rumah sakit umum tipe $B$ yang beralamat di Jalan Besar No. 77, Deli Tua Deli Serdang Provinsi Sumatera Utara. Sampel penelitian ini adalah pegawai RSU Sembiring Deli Tua, Tekhnik pengambilan sampel dalam penelitian ini adalah dengan menggunakan Purposive Sampling yaitu menentukan pengambilan sampel dengan cara menetapkan ciri-ciri khusus yang sesuai (sampel yang memenuhi kriteria inklusi) untuk menjadi sampel penelitian yang berjumlah 65 orang.

\section{HASIL PENELITIAN}

\section{Karakteristik Responden}

Data berikut adalah informasi yang berkaitan dengan karakteristik responden yang digunakan dalam penelitian ini. 
Damanik \& Bahri, Hubungan Pengetahuan Pegawai ...

Tabel 1. Distribusi Responden berdasarkan umur

\begin{tabular}{cccc}
\hline No & $\begin{array}{c}\text { Umur } \\
\text { (tahun) }\end{array}$ & $\mathbf{F}$ & $\mathbf{\%}$ \\
\hline 1 & $20-30$ & 40 & 61,5 \\
2 & $31-40$ & 25 & 38,5 \\
\hline & Total & $\mathbf{6 5}$ & $\mathbf{1 0 0}$ \\
\hline
\end{tabular}

Tabel 2. Distribusi Responden berdasarkan Jenis Kelamin

\begin{tabular}{cccc}
\hline No & $\begin{array}{c}\text { Jenis } \\
\text { Kelamin }\end{array}$ & F & \% \\
\hline 1 & Laki -Laki & 14 & 21,5 \\
2 & Prempuan & 51 & 78,5 \\
\hline & Jumlah & $\mathbf{6 5}$ & $\mathbf{1 0 0}$ \\
\hline
\end{tabular}

Tabel 3. Distribusi Responden berdasarkan Pendidikan

\begin{tabular}{clcc}
\hline No & Pendidikan & F & \% \\
\hline 1 & D3 & 19 & 29,2 \\
2 & Sarjana & 46 & 70,8 \\
\hline & Jumlah & $\mathbf{6 5}$ & $\mathbf{1 0 0}$ \\
\hline
\end{tabular}

Tabel 4. Distribusi Responden berdasarkan Lama Bekerja

\begin{tabular}{cccc}
\hline No & $\begin{array}{c}\text { Lama } \\
\text { Bekerja }\end{array}$ & $\mathbf{F}$ & $\mathbf{\%}$ \\
\hline 1 & $<5$ Tahun & 48 & 73,8 \\
2 & $>5$ Tahun & 17 & 26,2 \\
\hline & Jumlah & $\mathbf{6 5}$ & $\mathbf{1 0 0}$ \\
\hline
\end{tabular}

\section{Data Univariat}

Tabel 5. Distribusi Responden berdasarkan Pengetahuan

\begin{tabular}{ccc}
\hline Pengetahuan & F & \% \\
\hline Kurang & 35 & 53,8 \\
cukup & 16 & 24,6 \\
baik & 14 & 21,5 \\
Total & $\mathbf{6 5}$ & $\mathbf{1 0 0}$ \\
\hline
\end{tabular}

Tabel 6. Distribusi Responden berdasarkan Limbah Padat Medis

\begin{tabular}{ccc}
\hline $\begin{array}{c}\text { Pemilahan Limbah } \\
\text { Medis Padat }\end{array}$ & F & \% \\
\hline Ya & 19 & 29,2 \\
Tidak & 46 & 70,8 \\
\hline Total & $\mathbf{6 5}$ & $\mathbf{1 0 0}$ \\
\hline
\end{tabular}

\section{Data Bivariat}

Tabel 6. Hasil Tabulasi Silang

Pengetahuan Pegawai Dengan

Pemilahan Limbah Medis Padat

\begin{tabular}{|c|c|c|c|c|}
\hline \multirow{2}{*}{$\begin{array}{c}\text { Pengeta- } \\
\text { huan }\end{array}$} & \multicolumn{3}{|c|}{ Pemilahan Limbah } & \multirow{2}{*}{$\begin{array}{c}P \\
\text { Value }\end{array}$} \\
\hline & $\mathbf{Y a}$ & Tdk & Jlh & \\
\hline Kurang & 6 & 29 & 35 & \\
\hline Cukup & 4 & 12 & 16 & 0.004 \\
\hline Baik & 9 & 5 & 14 & \\
\hline
\end{tabular}

Hubungan Pengetahuan Pegawai Dengan Pemilahan Limbah Medis Padat

Hasil uji statistik pada pengetahuan dengan pemilahan limbah medis padat diketahui bahwa dari 65 responden yang menyatakan pengetahuan kurang dengan pemilahan limbah medis padat yang sebanyak 35 orang (53,8\%). Sedangkan responden yang menyatakan ada hubungan pengetahuan cukup dengan pemilahan limbah medis padat sebanyak 16 orang $(24,6 \%)$ dan yang menyatakan ada Hubungan pengetahuan baik dengan Pemilahan limbah medis padat sebanyak 14 orang $(21,5 \%)$ dengan nilai $P_{\text {value }}$ adalah 0.004 .

Berdasarkan hasil tersebut, maka dapat disimpulkan bahwa terdapat Hubungan Pengetahuan Dengan Pemilahan Limbah Medis Padat di Rumah Sakit Umum Sembiring Kecamatan Deli Tua Kabupaten Deli Serdang Tahun 2019. Pengetahuan petugas pelaksana berkaitan dengan segala sesuatu yang diketahui petugas pelaksana tentang penerapan K3 meliputi pengertian, tujuan, bahaya pemeriksaan kesehatan, APD, sampah/limbah.

Pengetahuan responden tentang pengelolaan sampah dengan baik dapat dibangun berdasar kemampuan berpikir 
sesuai dengan kenyataan yang responden lihat dan temukan di lingkungan sekitar responden berada. Hal ini menunjukkan bahwa pengetahuan merupakan hasil seseorang melakukan penginderaan terhadap obyek tertentu (Notoatmodjo, 2003).

Pengetahuan

responden mengenai cara pengelolaan limbah dengan cara penampungan dan pemusnahan dengan memisahkan limbah medis dengan non medis, sehingga responden sependapat bahwa antara tempat sampah medis dan non medis harus berbeda. Hal ini sejalan dengan tata cara penanganan sampah bahwa sampah dari setiap ruang/unit harus dapat dipisahkan sesuai dengan kategori atau jenis sampah dan dimasukkan ke tempat sampah yang telah disediakan oleh staf/personil yang bekerja pada ruang/unit yang bersangkutan (Bagoes, dkk, 2003).

\section{Pemilahan Limbah Medis Padat}

Hasil uji statistik pada pemilahan limbah medis padat diketahui bahwa dari 65 responden yang menyatakan membuang $\mathrm{Ya}$ dengan pemilahan limbah medis padat yang sebanyak 19 orang $(29,2 \%)$ dan yang menyatakan membuang Tidak dengan pemilahan limbah medis padat sebanyak 46 orang (70,8\%) dengan nilai $P_{\text {value }}$ adalah 0.004. Berdasarkan data tersebut, maka dapat disimpulkan bahwa terdapat Hubungan Pengetahuan Dengan Pemilahan Limbah Medis Padat di Rumah Sakit Umum Sembiring Kecamatan Deli Tua Kabupaten Deli Serdang Tahun 2019.

Limbah medis padat memiliki risiko yang tidak baik terhadap kesehatan seperti penularan penyakit. Seluruuh tenaga kesehatan di rumah sakit rentan terhadap risiko pengelolaan limbah medis. Penelitian ini bertujuan untuk mengetahui hubungan pengetahuan tenaga kesehatan terhadap pengelolaan limbah medis padat. Penelitian ini merupakan observasional komparatif yang dilakukan pada tenaga kesehatan di salah satu RSKIA Kota Bandung pada bulan Agustus 2016.

\section{KESIMPULAN}

Berdasarkan hasil penelitian yang telah dilaksanakan pada bulan Mei sampai dengan selesai kepada pegawai dalam hal ini dilakukan pada perawat dapat disimpulkan sebagai berikut :

Hasil penelitian pengetahuan pegawai dengan pemilahan limbah medis padat berdasarkan pengetahuan didapatkan bahwa responden pengetahuan responden Kurang yaitu sebanyak 35 (53,8\%), Cukup yaitu sebanyak $16 \quad(24,6 \%)$, dan pengetahuan responden Baik yaitu sebanyak 14 (21,5\%). Berdasarkan yang meembuang $\mathrm{Ya}$ sebanyak 19 $(29,2 \%)$ dan berdasarkan yang membuang Tidak sebanyak 46 (70,8\%).

Hasil uji statistik dengan menggunakan Chi-Square ( $p$-Value) sebesar $0,000<0,05$ artinya terdapat hubungan yang signifikan Pengetahuan Pegawai Dengan Pemilahan Limbah Medis Padat Di Rumah Sakit Umum Sembiring Deli Tua Kabupaten Deli Serdang Tahun 2019.

Penulisan sumber kutipan mengacu pada APA Style menggunakan format urutan alfabet dan 1 spasi. Daftar pustaka hanya memuat Pustaka yang secara langsung diacu atau menjadi sumber kutipan. Berikut adalah beberapa contoh penulisan daftar pustaka. 


\section{DAFTAR PUSTAKA}

\section{Buku:}

Pruss, Giroul, dan Rushbrook, 2005. Hubungan Pengetahuan dengan Perilaku Perawat dalam Membuang Limbah Medis Padat di RS Bhakti Wira Tamtama Semarang Tahun 2015.

Adisasmito, Wiku. 2007. Sistem Manajemen Lingkungan Rumah Sakit, PT. Raja Grafindo Persada, Jakarta.

Adisasmito, Wiku. 2008. Audit lingkungan rumah sakit. PT Raja Grafindo Persada, Jakarta.

Notoatmodjo, S. 2007. Kesehatan Masyarakat Ilmu dan Seni. Jakarta : Rineka Cipta

Notoatmodjo, S. 2010. Metodologi Penelitian Kesehatan. Jakarta : Rineka Cipta.

Martini, 2007. Hubungan Karakteristik, Beban Kerja, Ketersediaan Fasilitas Dengan Pendokumentasian Asuhan Keperawatan di RSUD Kota Salatiga.

Arikunto, S. (2013). Prosedur Penelitian: Suatu Pendekatan Praktik. Jakarta: Rineka Cipta.

Sugiyono. (2014). Metode Penelitian Kuantitatif, kualitatif, dan R\&D. Bandung: Penerbit Alfabeta.

Dahlan, Sopiyudin., 2011. Statistik Untuk Kedokteran dan Kesehatan Edisi 5.Jakarta, Salemba Medika. 